\title{
GAL Gene Product
}

National Cancer Institute

\section{Source}

National Cancer Institute. GAL Gene Product. NCI Thesaurus. Code C148349.

A protein encoded by the GAL gene. 